\title{
CHRONIC HEPATITIS C IN THE CZECH REPUBLIC: FORECASTING THE DISEASE BURDEN
}

\author{
Soňa Fraňková', Petr Urbánek², Petr Husa ${ }^{3}$, Vratislav Němeček ${ }^{4}$, Homie Razavi ${ }^{5}$, Devin Razavi-Shearer ${ }^{5}$, \\ Roman Chlíbek $^{6}$, Jan Šperl ${ }^{1}$ \\ 'Department of Hepatogastroenterology, Institute for Clinical and Experimental Medicine, Prague, Czech Republic \\ ${ }^{2}$ Department of Internal Medicine, First Faculty of Medicine, Charles University and Central Military Hospital, Prague, Czech Republic \\ ${ }^{3}$ Clinic of Infectious Diseases, University Hospital Brno, Masaryk University, Brno, Czech Republic \\ ${ }^{4}$ National Reference Laboratory for Hepatitis, National Institute of Public Health, Prague, Czech Republic \\ ${ }^{5}$ Center for Disease Analysis, Lafayette, Colorado, USA \\ ${ }^{6}$ Department of Epidemiology, Vaccination Centre, Faculty of Military Health Sciences, University of Defence, Hradec Králové, Czech Republic
}

\section{SUMMARY}

Objective: Chronic HCV infection is associated with cirrhosis of the liver, hepatocellular carcinoma (HCC), and liver transplantation. HCV disease burden and the impact of new potent direct acting antivirals (DAAs) in the Czech Republic are unknown.

Methods: Using a modelling framework, HCV disease progression in the Czech Republic was predicted to 2030 under the current standard of care treatment structure. In addition, two strategies to reduce the future burden of HCV infection were modelled: an incremental increase in treatment annually and WHO targets.

Results: The number of viremic infected individuals in the Czech Republic is estimated to peak in 2026 ( $n=55,130)$ and to decline by $0.5 \%$ by $2030(n=54,840)$. The number of individuals with compensated cirrhosis $(n=1,400)$, decompensated cirrhosis $(n=80), H C C(n=70)$, and liverrelated deaths $(n=60)$ is estimated to more than double by 2030. Through aggressive increases in diagnosis and treatment, HCV related mortality may decrease by $70 \%$ by 2030 .

Conclusions: Disease burden associated with chronic HCV infection is projected to peak in the Czech Republic in $30-40$ years. Assuming that the current portion of DAAs used remains constant, a significant reduction in HCV disease burden is possible through increased diagnosis and treatment through 2030. This analysis provides evidence in order to facilitate the development of national strategies for HCV care and management in the Czech Republic.

Key words: hepatitis C, disease burden, epidemiology, Czech Republic

Address for correspondence: S. Fraňková, Department of Hepatogastroenterology, Institute for Clinical and Experimental Medicine, Vídeňská 1958/9, 14021 Prague 4, Czech Republic. E-mail: sona.frankova@ikem.cz

https://doi.org/10.21101/cejph.a5350

\section{INTRODUCTION}

Infection associated with chronic $\mathrm{HCV}$ is a major cause of liver disease in Europe (1). In the Czech Republic, compared with other European countries, the $\mathrm{HCV}$ epidemic began later owing to geographical barriers, limited immigration from neighbouring endemic countries and a delayed surge in injection drug use. However, in recent years, $\mathrm{HCV}$ infection has become one of the leading causes of liver transplantation in the Czech Republic (2). As the infected cohort ages, the burden of HCV-related disease is expected to increase greatly.

The Czech Republic is a low-endemic country for HCV infection with reported anti-HCV positivity estimates between $0.2-1.0 \%$ (3-5); nevertheless, little is known on the national level regarding current and future disease burden. There is no general screening programme in the Czech Republic. To date, only specific subgroups are screened on a regular basis. These groups include: blood donors, healthcare workers, patients on maintenance hemodialysis, prisoners and drug users starting weaning programmes. HCV prevalence varies widely between these groups with the lowest prevalence reported among blood donors in Prague (0.13\%) and the highest prevalence reported among injection drug users (IDU) $(58.6 \%)(6,7)$.

In the Czech Republic, interferon-free direct-acting antiviral (DAA) combinations were approved for reimbursement in 2014. The current standard of care in the Czech Republic allows for unrestricted treatment; however, in light of the aforementioned factors and cost of DAAs and budget restrictions, those that are older and that have progressed further are prioritized. With the introduction of new generations of DAAs, treatment has resulted in higher sustained virological response (SVR) rates, fewer side effects and more simple regimens.

In this study, a modelling approach was used to analyze the progression of HCV disease burden in the Czech Republic; to assess two strategies for addressing chronic $\mathrm{HCV}$ infection: the effects of incremental increases in treatment and aggressive diagnosis and treatment; and to review the impact of these strategies on future disease burden, considering strategy implementation. 


\section{MATERIALS AND METHODS}

A detailed description of the model and methodology has been reported on extensively (8). The infected HCV population was characterized using published literature, Czech Government reports and estimates from a panel of the country experts. Czech population data were obtained by 5 -year age and gender cohorts from the United Nations World Population Prospects (9). Estimates of historic and future population were obtained for the years 1950-2100.

\section{Baseline Population Characteristics}

Current anti-HCV prevalence for the general population was estimated using a recent prospective multicentre observation seroprevalence study of 3,000 healthy adult subjects aged 18 and older (5). The HCV prevalence was estimated by taking into account the number of people who inject drugs, and the age and gender distribution of all included populations in the study. The viremic prevalence in the general population in the Czech Republic was estimated to be $0.5 \%(0.2-0.63 \%)$ in 2015 (5). As all reported $\mathrm{HCV}$ cases were RNA positive, the viremic rate was set to $100 \%$. The age and gender distribution was developed using data from 2015, supplied by The National Institute of Public Health, which were reported to the EPIDAT system (Fig. 1) (10). Genotype studies in the Czech Republic are often limited to selected populations such as blood donors (11) and IDUs $(3,12)$. The genotype distribution (Table 1) was reported by Nemecek et al. $(4,11)$ and Chlibek et al. (5) estimating a relatively even split between genotype 1 and genotype 3 .

In 1998, blood transfusion was reported as a risk factor of HCV transmission in $15.0 \%$ of patients (13). Transmission of HCV infection through transfusion has been declining since 1992 after introduction of blood donors screening and is no longer considered a risk factor for transmission. The most common route of HCV transmission in the Czech Republic is through injection drug use. In 2015, 51.1\% of injection drug users were found to be

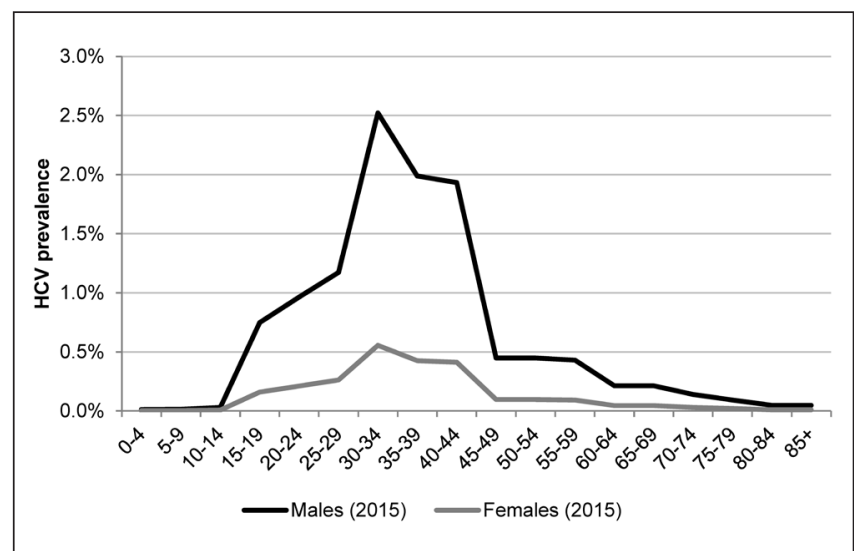

Fig. 1. Age and gender distribution of anti-HCV prevalence in the Czech Republic, 2015. positive for anti-HCV (5). In 2015, it was estimated that $15.6 \%$ of prevalent cases were current injection drug users $(5,7)$.

There is limited data available on the incidence of new cases of $\mathrm{HCV}$ in the Czech Republic. An incidence curve for the estimation of new cases was developed based on discussions regarding the natural history of HCV disease in the Czech Republic with the expert panel. The annual number of new cases in the Czech Republic is considered to have peaked in 2009 before decreasing. It is believed that the number of new cases arising annually is relatively stable in light of continued transmission through intravenous drug usage. In 2016, there were estimated 1,740 new cases of reported acute and chronic HCV in the Czech Republic. The data described above are summarized in Table 2.

\section{Mortality and Liver Related Morbidity}

Background mortality for the years was collected by five-year age and gender cohorts using the United Nations Population Database (9). Increased mortality among the transfusion-acquired $\mathrm{HCV}$ and IDU-acquired HCV was accounted for by applying a standard mortality rate of 2.1 and 10.0, respectively, for the affected age groups (14-20). Age and gender specific transition probabilities were used to progress patients annually through each disease state. A more detailed description has been described elsewhere (8).

Liver transplant data from 2001-2013 was available through the International Registry on Organ Donation and Transplantation (IRODaT) (21). Transplant data from 2013-2016 was available from the transplant centres (22). In 2016, there were 177 liver transplants performed in the Czech Republic with 18 being due to $\mathrm{HCV}$. In all years prior to 2013 , it is estimated that $15.6 \%$ of transplants are attributable to HCV (2).

\section{Modeled Base Case and Treatment Strategies}

A base case and two treatment strategies, incremental increase in treatment and WHO targets, were modelled in the Czech Republic.

It is estimated that in 2016, 910 patients were treated in the Czech Republic, with the majority being treated with DAAs. DAAs were first introduced in the Czech Republic in 2014, thus allowing for an increased patient eligibility pool. Audit data was used to estimate the total number of treated patients in 2015 and 2016. The total number of treated patients decreased from approximately 1,050 in 2015 to 910 in 2016, but the number treated with DAAs increased from 270 to over 570 .

In 2015, there were estimated to be 17,300 viremic individuals in the Czech Republic living with a diagnosis. Each year, an estimated 1,100 viremic individuals are newly diagnosed $(5,10)$. Treatment and diagnosis estimates for 2015 are shown in Table 2.

In the base case, the estimates of SVR rates were based on real-life SVR, clinical studies and expert opinion (23-27). There are currently no treatment restrictions based on age; however, treatment is restricted to those $\geq \mathrm{F} 1$. The efforts for the strategies outlined below assume that no further restrictions will be enacted.

Table 1. HCV genotype distribution in the Czech Republic, 2015

\begin{tabular}{|l|c|c|c|c|c|c|c|c|}
\hline Genotype & 1a & 1b & 1 other & $\mathbf{2}$ & $\mathbf{3}$ & $\mathbf{4}$ & $\mathbf{5}$ & $\mathbf{6}$ \\
\hline Percent & $26 \%$ & $26 \%$ & $0 \%$ & $0 \%$ & $48 \%$ & $0 \%$ & $0 \%$ & $0 \%$ \\
\hline
\end{tabular}


Table 2. Model inputs and 2016 estimations

\begin{tabular}{|c|c|c|c|}
\hline & $\begin{array}{c}\text { Historical } \\
\text { (min max uncertainty interval) }\end{array}$ & Year & 2016 (Est.) \\
\hline HCV infected cases & $53,200(21,300-67,000)$ & 2015 & 53,500 \\
\hline Total viremic cases & $53,200(21,300-67,000)$ & 2015 & 53,500 \\
\hline Viremic prevalence & $0.5 \%(0.2-0.6 \%)$ & & $0.5 \%$ \\
\hline HCV diagnosed (viremic) & 17,300 & 2015 & 17,400 \\
\hline Viremic diagnosis rate & $32.5 \%$ & & $32.5 \%$ \\
\hline Annual newly diagnosed & 1,100 & 2016 & 1,100 \\
\hline New infections & & & 1,740 \\
\hline New infection rate (per 100,000 ) & & & 16.0 \\
\hline \multicolumn{4}{|l|}{ Treated } \\
\hline Number treated & 900 & 2016 & 910 \\
\hline Annual treatment rate & $1.7 \%$ & & $1.7 \%$ \\
\hline \multicolumn{4}{|l|}{ Risk factors } \\
\hline Number of active IDU with HCV & & & 8,300 \\
\hline Percent active IDU & & & $15.6 \%$ \\
\hline Previous blood transfusion & & & 0 \\
\hline Percent previous blood & & & $0.0 \%$ \\
\hline \multicolumn{4}{|l|}{ Liver transplants } \\
\hline Total number of liver transplants & 177 & 2016 & \\
\hline Liver transplants due to HCV & 18 & 2016 & \\
\hline Annual number cured & 800 & 2016 & \\
\hline Average SVR rate & $90 \%$ & 2016 & \\
\hline General population* & $10,565,284$ & 2015 & \\
\hline
\end{tabular}

HCV - hepatitis C virus; IDU - intravenous drug user; SVR - sustained virological response; *Mid-year population in 2016 according to the Czech Statistical Office.

In the Czech Republic, there is a planned increase in treatment of $10 \%$ annually owing to the regular annual increase in budgets allocated for HCV therapy by healthcare payers. In order to observe the effects of a slightly more aggressive strategy a scenario has been created that increases the number treated by $15 \%$ annually while keeping the SVR the same as the base case. By 2025, the number of individuals diagnosed annually must be increased to 2,130 in order to keep pace with the number of treated patients.

To significantly reduce HCV burden in the Czech Republic, a second strategy with aggressive diagnosis and treatment strategy was developed to achieve the WHO targets of $90 \%$ of the infected population being diagnosed and $65 \%$ reduction in liver related mortality (28). Beginning in 2019, screening efforts (29) result in 2,000 new diagnoses per year, a $100 \%$ increase from 2015 , with an associated $200 \%$ increase in treatment across genotypes to 3,000 patients. To achieve reductions, additional increases in diagnosis and treatment were applied in each subsequent wave. By 2024, an estimated 3,500 patients will receive treatment annually and expand to 4,900 patients treated in 2025. This figure continues through 2030.

\section{RESULTS}

\section{Base Case}

In 2015, there were estimated 53,200 infected individuals in the Czech Republic. The age distribution of the 2015 viremic

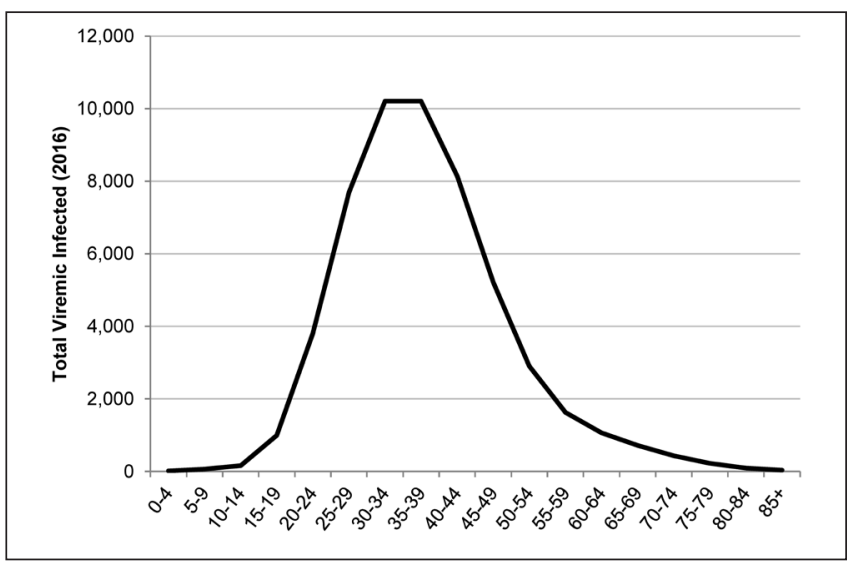

Fig. 2. Total viremic cases by age, 2016 (base case model output).

population with chronic HCV is shown in Figure 2. By 2030, as the infected cohort ages, liver-related mortality is forecasted to increase by $100 \%$.

The viremic infected population is anticipated to peak in 2026 with 55,130 individuals (Figures 3 and 5). By 2030, the number of individuals progressing to decompensated cirrhosis, hepatocellular carcinoma (HCC), and liver-related deaths will increase by $146 \%$ and $77 \%$, and $116 \%$, respectively, from 2015 (Figures 4 and 5). 


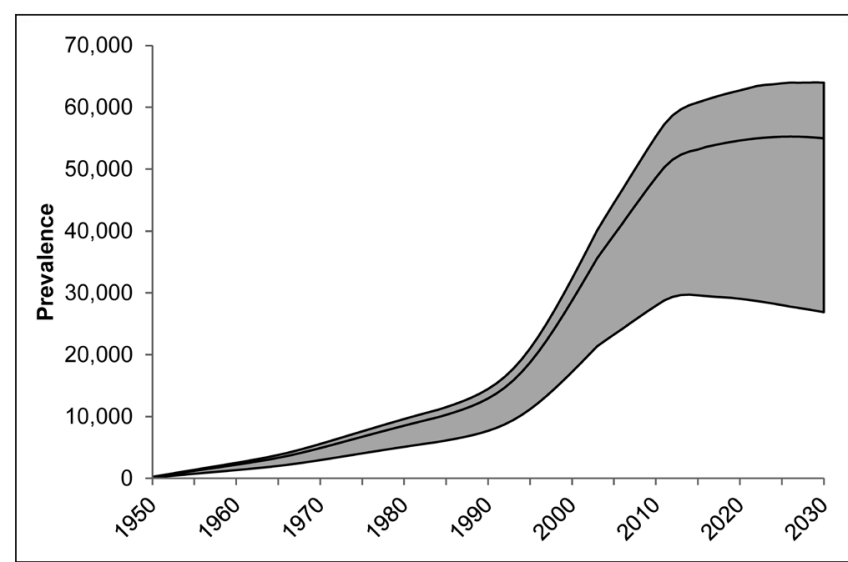

Fig. 3. Total viremic cases by year, 1950-2030 (base case model output).

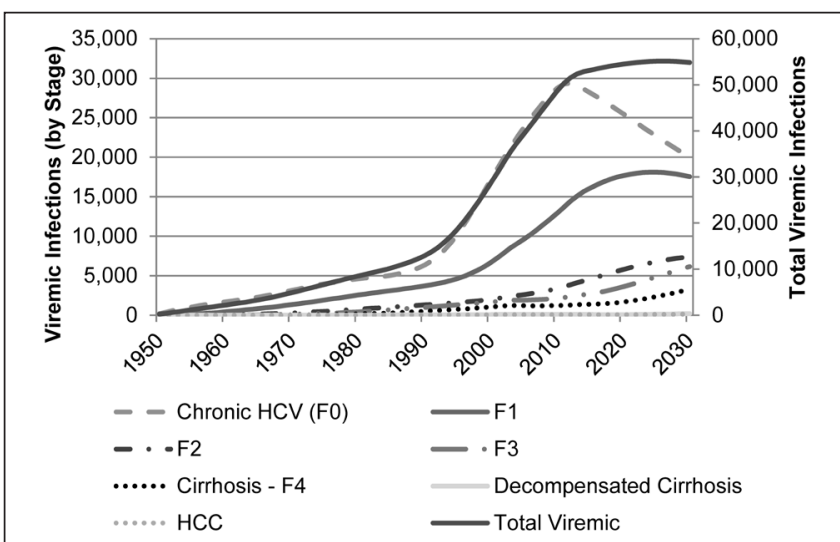

Fig. 4. Number of viremic cases in total and by disease stage, 1950-2030 (base case model output).

\section{Incremental Increase in Treatment}

The total viremic population is forecasted to decrease at a faster rate than under the base case scenario, with 39,900 viremic individuals in 2030 corresponding to a $25 \%$ decrease (Figures 3 and 5). In this scenario, HCV related mortality would decrease by $41 \%$ by 2030 corresponding to 480 lives saved.

Additionally, by 2030, the number of individuals with decompensated cirrhosis will decrease to 40 individuals, and the number of HCC cases will decrease to 100, a 52-59\% improvement over the base case forecast for 2030 (Fig. 5).

\section{WHO Targets}

Based on WHO elimination strategy (28), modelling an aggressive diagnosis and treatment strategy resulted in an $81 \%$ reduction in the total viremic population by 2030 with only 10,000 cases remaining in 2030 . This strategy results in a $70 \%$ decrease in HCV-related mortality, correlating to 640 lives saved.

By 2030, the number of individuals with decompensated cirrhosis will decrease to fewer than 20 individuals and the number of individuals with HCC to fewer than 20.

\section{DISCUSSION}

Modelling has been demonstrated to be effective in predicting $\mathrm{HCV}$ disease burden. In the present study, a modelling approach to forecast the future burden of $\mathrm{HCV}$ related liver disease through 2030 was used for the Czech Republic. Using data derived from published literature, unpublished government reports and expert opinion, it forecasted that the infected viremic population in the

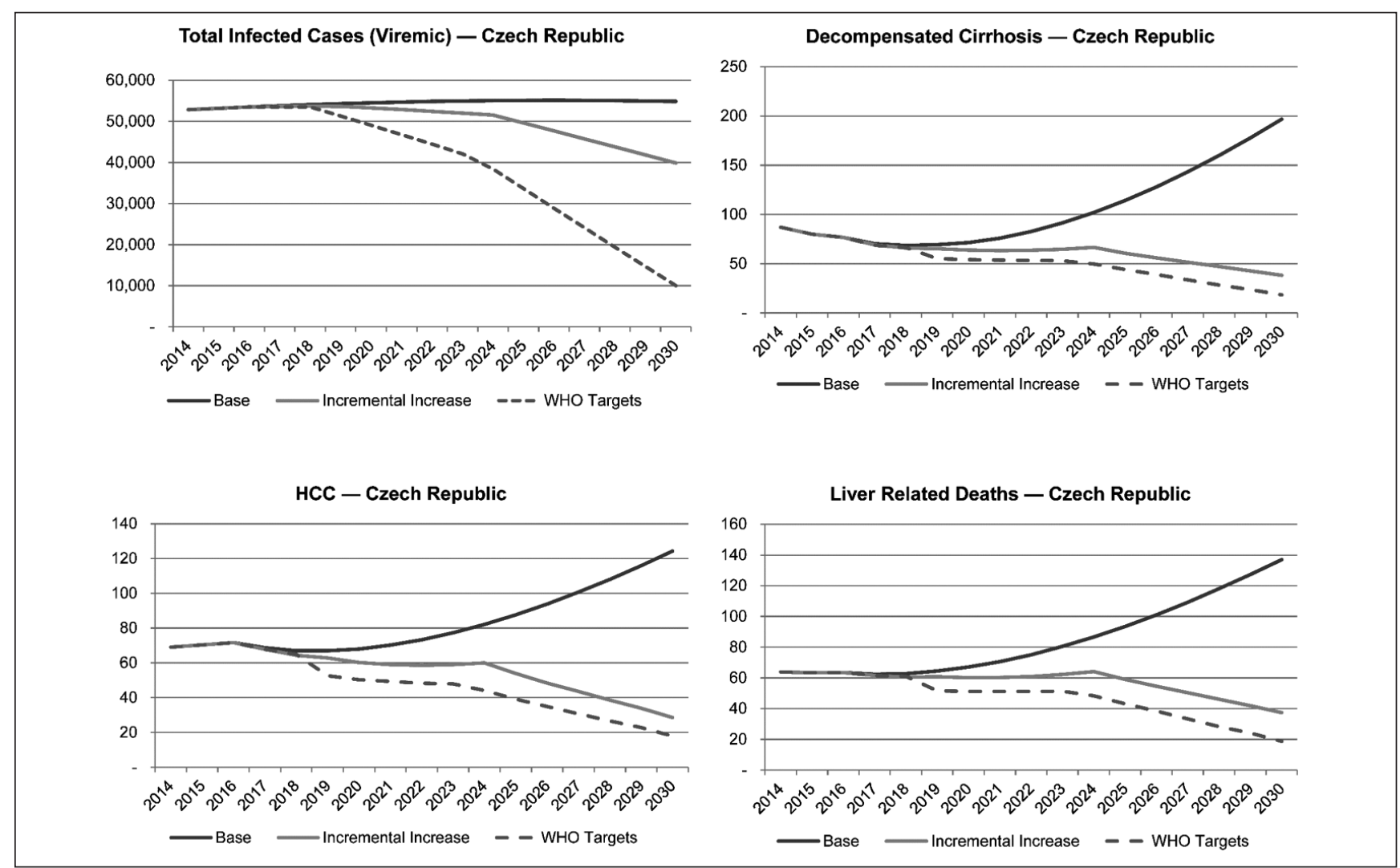

Fig. 5. Morbidity and mortality by strategy and by year, 2013-2030. 
Czech Republic is increasing with a peak prevalence of 55,130 infected individuals in 2026 before beginning to decline.

While keeping the same treatment efficacy, but increasing treatment annually by $15 \%$, a moderate reduction, $25 \%$, in the total number of viremic infections will occur. Nevertheless, by keeping the fibrosis restriction at $\geq \mathrm{F} 1$, the $\mathrm{HCV}$ related morbidity and mortality are expected to decrease by up to $59 \%$. In order for this scenario to take place, there would need to be an increase in screening starting in 2025.

A strategy was modelled wherein aggressive increases in screening and treatment were applied to achieve WHO targets (28). Assuming an increase in screening and treatment, the total viremic infected is anticipated to decrease to 10,000 infected individuals in 2030. This reduction assumes no fibrosis staging or age restrictions starting in 2019. Moreover, it assumes an increase in diagnosis from 960 individuals a year in 2015 to just over 6,200 individuals by 2025 .

A reliable general screening programme is crucial to $\mathrm{HCV}$ elimination in the Czech Republic. Both increases in diagnosis and treatment must be implemented to achieve significant reductions in disease burden. Czech screening programmes that have already been adopted have contributed significantly to a decrease in nosocomial transmission of HCV infection. For example, in patients on maintenance hemodialysis, there has been a decrease in anti-HCV prevalence from $30 \%$ in the 1990 s to less than $5 \%$ to date (30). With rapidly evolving care for $\mathrm{HCV}$ patients and increasingly effective and tolerated all-oral antiviral regimens, all patients identified by means of screening programmes could receive antiviral treatment. Based on the recommendations for birth cohort screening developed by the Centers for Disease Control and Prevention (CDC) in the United States, the most effective screening programme in the Czech Republic would be to target individuals born between 1958 and 1993 (31). This population cohort reflects $70 \%$ of the infected viremic population.

A limitation of this analysis is the unknown future genotype structure in the Czech Republic. Historically, genotype $1 \mathrm{~b}$ was the most prevalent genotype in the Czech Republic. More than $90 \%$ of treated individuals in the 1990 s and $99 \%$ of patients indicated for liver transplantation for HCV infection from 1995 to 2013 were infected with genotype $1(2,32,33)$. In addition, more than $50 \%$ of viremic patients in the Czech Republic have low pretreatment viremia, representing a positive predictive factor of response to treatment. Most Czech centres reported an SVR rate 55-60\% with Peg-IFN- $\alpha$ and ribavirin treatment in the cohorts of genotype $1 b$ patients, slightly higher than SVR rates reported in clinical trials (30). However, owing to immigration from endemic countries and increasing $\mathrm{HCV}$ prevalence among IDUs over the last 20 years, the rate of genotype 3 in new HCV cases is rising: $31.1 \%$ in 2012 and $46.4 \%$ in 2015, whereas the proportion of other genotypes (G2, G4, etc.) is negligible $(5,11)$. Fortunately, the new generation directacting antivirals are pangenotypic with an excellent efficacy across genotypes and independently of pretreatment viremia (34), therefore, we do not presume a lower treatment efficacy in genotype 3 patients.

\section{CONCLUSIONS}

Owing to a later onset of peak infectivity, the Czech Republic is in a unique situation to curb the coming epidemic of $\mathrm{HCV}$ morbidity and mortality providing there is a commitment to large scale screening with linkage to care.

\section{Conflict of Interests}

None declared

\section{REFERENCE}

1. Mühlberger N, Schwarzer R, Lettmeier B, Sroczynski G, Zeuzem S, Siebert U. HCV-related burden of disease in Europe: a systematic assessment of incidence, prevalence, morbidity, and mortality. BMC Public Health. 2009 Jan 22;9:34. doi: 10.1186/1471-2458-9-34.

2. Šperl J, Fraňková S, Trunečka P. Liver transplantation for chronic C hepatitis, significance for antivirus treatments. Gastroenterol Hepatol. 2013;67(5):407-12.

3. Krekulova L, Rehak V, Madrigal N, Johnson M, Killoran P, Riley LW. Genotypic and epidemiologic characteristics of hepatitis $\mathrm{C}$ virus infections among recent injection drug user and nonuser populations. Clin Infect Dis. 2001;33(8):1435-8.

4. Nemecek V, Castkova J, Fritz P, Linhartova A, Svandova E, Sramova H, et al. The 2001 serological survey in the Czech Republic - viral hepatitis. Cent Eur J Public Health. 2003;11 Suppl:S54-61.

5. Chlibek R, Smetana J, Sosovickova R, Gal P, Dite P, Stepanova V, et al. Prevalence of hepatitis $\mathrm{C}$ virus in adult population in the Czech Republic - time for birth cohort screening. PLoS One. 2017;12(4):e0175525. doi: 10.1371/journal.pone.0175525.

6. Č́stková J. Epidemiology of viral hepatitis B and C in the Czech Republic [Internet]. Prague: NIPH [cited 2019 Jun 7]. Available from: https://www. ces-hep.cz/file/272/04_castkova.pdf. (In Czech.)

7. National Monitoring Centre for Drugs and Addiction. Annual report on the state of all narotics in th Czech Republic in the year 2015 [Internet]. Prague: Office of the Government of the Czech Republic; 2016 [cited 2019 Apr 25]. Available from: https://www.drogy-info.cz/publikace/ vyrocni-zpravy/vyrocni-zprava-o-stavu-ve-vecech-drog-v-ceskerepublice-v-roce-2015/. (In Czech.)

8. Razavi H, Waked I, Sarrazin C, Myers RP, Idilman R, Calinas F, et al. The present and future disease burden of hepatitis $\mathrm{C}$ virus (HCV) infection with today's treatment paradigm. J Viral Hepat. 2014;21 Suppl 1:34-59.

9. United Nations, Department of Economic and Social Affairs. World population prospects. The 2015 revision: key findings and advance tables [Internet]. New York: United Nations; 2015 [cited 2018 Mar 25]. Available from: https:/www.un.org/development/desa/publications/ world-population-prospects-2015-revision.html.

10. National Institute of Public Health. Selected infectious diseases in the Czech Republic in 2008 - 2017 in absolute numbers [Internet]. Prague: NIPH [cited 2018 Mar 25]. Available from: http://www.szu.cz/publikace/ data/2017/vybrane-infekcni-nemoci-v-cr-v-letech-2008-2017-absolutne. (In Czech.)

11. Němeček V, Strunecký O. Genotypic heterogeneity of hepatitis $\mathrm{C}$ virus (HCV) from blood donors in the Czech Republic. Epidemiol Mikrobiol Imunol. 2009 Apr;58(2):63-72. (In Czech.)

12. Krekulová L, Řehák V, Strunecký O, Němeček V. Current situation and trends in the hepatitis $\mathrm{C}$ virus genotype distribution among injecting drug users in the Czech Republic. Epidemiol Mikrobiol Imunol. 2009 Apr;58(2):84-9. (In Czech.)

13. Urbánek P, Mareček Z, Brodanová M, Brůha R, Kaláb M, Petrtýl J. Risk factors for transmission of hepatitis $\mathrm{C}$ in the Czech population. Cas Lek Cesk. 2002 Mar 29;141(6):185-8. (In Czech.)

14. Engstrom A, Adamsson C, Allebeck P, Rydberg U. Mortality in patients with substance abuse: a follow-up in Stockholm County, 1973-1984. Int J Addict. 1991;26(1):91-106.

15. Frischer M, Goldberg D, Rahman M, Berney L. Mortality and survival among a cohort of drug injectors in Glasgow, 1982-1994. Addiction. 1997;92(4):419-27.

16. Hickman M, Carnwath Z, Madden P, Farrell M, Rooney C, Ashcroft R, et al. Drug-related mortality and fatal overdose risk: pilot cohort study of heroin users recruited from specialist drug treatment sites in London. J Urban Health. 2003;80(2):274-87.

17. Oppenheimer E, Tobutt C, Taylor C, Andrew T. Death and survival in a cohort of heroin addicts from London clinics: a 22-year follow-up study. Addiction. 1994;89(10):1299-308. 
18. Perucci CA, Davoli M, Rapiti E, Abeni DD, Forastiere F. Mortality of intravenous drug users in Rome: a cohort study. Am J Public Health. 1991;81(10):1307-10.

19. Bjornaas MA, Bekken AS, Ojlert A, Haldorsen T, Jacobsen D, Rostrup $\mathrm{M}$, et al. A 20-year prospective study of mortality and causes of death among hospitalized opioid addicts in Oslo. BMC Psychiatry. 2008 Feb 13;8:8. doi: 10.1186/1471-244X-8-8,

20. Kamper-Jorgensen M, Ahlgren M, Rostgaard K, Melbye M, Edgren G, Nyren O, et al. Survival after blood transfusion. Transfusion. 2008;48(12):2577-84.

21. IRODaT [Internet]. Barcelona: IRODaT - DTI Foundation [cited 2018 Mar 25]. Available from: http://www.irodat.org/?p=database\&c=CZ\#data.

22. European Union HCV Collaborators. Hepatitis $\mathrm{C}$ virus prevalence and level of intervention required to achieve the WHO targets for elimination in the European Union by 2030: a modelling study. Lancet Gastroenterol Hepatol. 2017 May;2(5):325-36.

23. McHutchison JG, Lawitz EJ, Shiffman ML, Muir AJ, Galler GW, McCone $\mathrm{J}$, et al. Peginterferon alfa-2b or alfa-2a with ribavirin for treatment of hepatitis C infection. N Engl J Med. 2009;361(6):580-93.

24. Manns M, Zeuzem S, Sood A, Lurie Y, Cornberg M, Klinker H, et al. Reduced dose and duration of peginterferon alfa- $2 \mathrm{~b}$ and weight-based ribavirin in patients with genotype 2 and 3 chronic hepatitis C. J Hepatol. 2011;55(3):554-63.

25. Jacobson IM, Brown RS, Jr., Freilich B, Afdhal N, Kwo PY, Santoro J, et al. Peginterferon alfa- $2 \mathrm{~b}$ and weight-based or flat-dose ribavirin in chronic hepatitis C patients: a randomized trial. Hepatology. 2007;46(4):971-81.

26. Husa P, Oltman M, Ivanovski L, Rehak V, Messinger D, Tietz A, et al. Efficacy and safety of peginterferon alpha-2a $(40 \mathrm{kD})$ plus ribavirin among patients with chronic hepatitis $\mathrm{C}$ and earlier treatment failure to interferon and ribavirin: an open-label study in central and Eastern Europe. Eur J Gastroenterol Hepatol. 2011 May;23(5):375-81.
27. Sperl J, Frankova S, Senkerikova R, Neroldova M, Hejda V, Volfova $\mathrm{M}$, et al. Relevance of low viral load in haemodialysed patients with chronic hepatitis C virus infection. World J Gastroenterol. 2015 May 14;21(18):5496-504.

28. World Health Organization. Global health sector strategy on viral hepatitis 2016-2021: towards ending viral hepatitis [Internet]. Geneva: WHO; 2016 [cited 2018 Mar 25]. Available from: http://www.who.int/hepatitis/ strategy2016-2021/ghss-hep/en/.

29. Urbánek P, Husa P, Šperl J, Fraňkova S, Plíšek S, Rožnovský P, et al. Standard diagnostic and therapeutic approach to chronic hepatitic $\mathrm{C}$ virus (HCV) infection - guidelines. Klin Mikrobiol Infekc Lek. 2017 Mar;23(1):22-40. (In Czech.)

30. Wedemeyer H, Duberg AS, Buti M, Rosenberg WM, Frankova S, Esmat $\mathrm{G}$, et al. Strategies to manage hepatitis $\mathrm{C}$ virus (HCV) disease burden. J Viral Hepat. 2014;21 Suppl 1:60-89.

31. Smith BD, Morgan RL, Beckett GA, Falck-Ytter Y, Holtzman D, Teo $\mathrm{CG}$, et al. Recommendations for the identification of chronic hepatitis $\mathrm{C}$ virus infection among persons born during 1945-1965. MMWR Recomm Rep. 2012;61(RR-4):1-32.

32. Bruggmann P, Berg T, Ovrehus AL, Moreno C, Brandao Mello CE, Roudot-Thoraval F, et al. Historical epidemiology of hepatitis $\mathrm{C}$ virus (HCV) in selected countries. J Viral Hepat. 2014;21 Suppl 1:5-33.

33. Urbánek P, Kristian P, Makara M, Hunyady B, Tomasziewicz K. Epidemiology of HCV infection in the Central European region. Clin Exp Hepatol. 2016 Mar;2(1):2-6.

34. European Association for the Study of the Liver. EASL Recommendations on Treatment of Hepatitis C 2018. J Hepatol. 2018;69(2):461-511.

Received March 25, 2018 Accepted in revised form April 25, 2019 